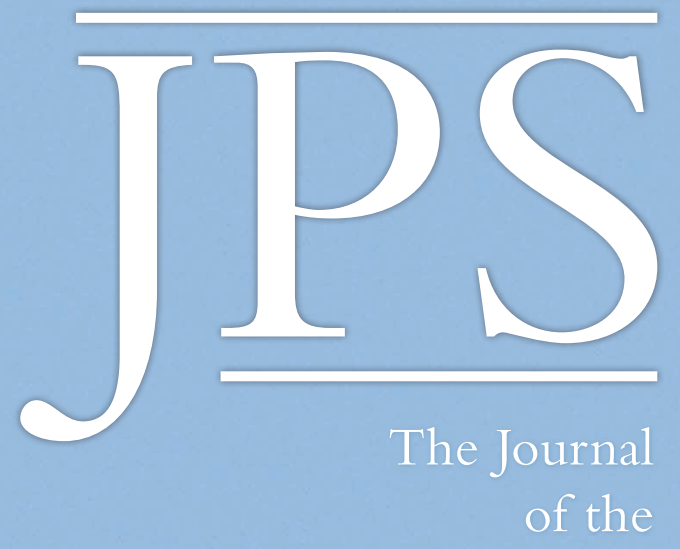

Polynesian Society

VOLUME 126 No.3 SEPTEMBER 2017

THE POLYNESIAN SOCIETY THE UNIVERSITY OF AUCKLAND NEW ZEALAND
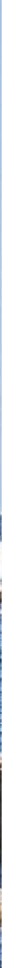


\title{
INSTRUMENTS IN MOTION: \\ FLUTES, HARMONICAS AND THE INTERPLAY OF SOUND AND SILENCE IN COLONIAL MICRONESIA
}

\author{
BRIAN DIETTRICH \\ Victoria University of Wellington
}

\begin{abstract}
The few native musical instruments are now obsolete or nearly so and are replaced by the guitar, harmonica, and ukulele (Fischer and Fischer 1957: 203)
\end{abstract}

Music enters the history of empire as silence (Bohlman 2016: 174)

While I was residing in the islands of Chuuk in the Federated States of Micronesia, friends told me a story about a musical instrument no longer seen or heard in the islands but not completely without a presence. I first listened to this tale in 2001 and again in subsequent years. In accounts of the story-said to date from the German colonial administration (1899-1914) - the identity of the instrument was not always clear, but most believed it to be the aangún, a nose flute made of bamboo or mangrove root but not regularly constructed or played since the mid-20th century. The word aangún can be translated as 'soft-sounder', a term that designates its delicate tone, but the name also calls to mind its quiet place in histories of Chuuk. The story about the instrument relates how a group of men from one village planned to ambush those from another as part of traditional warfare practices. Although the warring party disguised their plans, one knowledgeable man who knew how to play the instrument sounded a coded warning to his village after he learned about the intentions of the visitors. Narrators related to me how at that time people could no longer understand the meaning of the instrument, and because the message was not understood, people died in the ensuing battle. This oral history suggests an anxiety about efficacious cultural things long after they have been discarded in the islands, and it also underlines some of the challenges in coming to terms with material and musical pasts of the Pacific.

In contrast to this local account, the written descriptions of the aangún from the mid-20th century explained the flute and its disappearance in relation to the pressures of missionisation and colonialisation. In these inscribed narratives flutes were quickly displaced by the imposition of European instrumentsparticularly harmonicas and accordions - and they remained only in museums as obsolete relics of a supposed pre-colonial music culture. These divergent narratives about the Chuukese nose flute reveal outstanding questions of local agency and the complexity that surrounds sensorial, ephemeral things of colonial pasts in the Pacific. 
This article explores musical instruments in colonial Micronesia in their sonic, material and historical contexts. ${ }^{1}$ It focuses in particular on the Chuukese aangún, but also on instruments adopted during colonial administrations in the late 19th and early 20th centuries. The movements of instruments during this period reflected the broader social and material entanglements that took place within Micronesian communities. In this study I argue that critical attention to the unfolding of sound and silence within imperial enterprises in the Pacific offers insights into cultural agency within the turbulence of colonial contexts. An examination of the movements of things, including the abandonment of some instruments and the acceptance of others, addresses the choices of musicians and listeners within a musical and material modernity. Part I of this article situates the study of Micronesian flutes within scholarship on instruments, materiality and colonialism in the Pacific. I undertake a comparative mapping of historical reports about flutes in the Caroline and Mariana Islands as case examples of the unfolding silence brought by colonial domains. Part II focuses specifically on the Chuukese aangún, on its material and sonic forms and its past social contexts. In Part III I explore the circulation of musical instruments in the islands and internationally, as well as the incorporation of new colonial instruments as part of emerging practices from this period. Through my investigation of flutes and other instruments I query how we understand the movement and integrations of musical things in their material and aesthetic forms.

\section{PART I. SILENT INSTRUMENTS}

\section{Micronesia and Musical Instruments}

Musical instruments are especially complex things in their multi-sensorial and social materiality. While scholars have historically viewed instruments as objects of cultural-musical domains (Dawe 2012), research has only begun to question our past and present social relationships with them (Bates 2012; Dawe 2012). Recent research with instruments intersects with a broader focus on materiality and things (Bell and Geismar 2009; Harvey and Knox 2014) that has brought a renewed attentiveness to their movements and itineraries (Hahn and Weiss 2013; Joyce and Gillespie 2015), as well as their pathways and impermanence (Hodder 2011) and the ever-flowing processes of "making, growth, and transformation" (Ingold 2012: 435). Examined over time and especially through colonial entanglements (Thomas 1991), instrumental practices in the Pacific Islands have been integral to processes of cultural revival and renewal (Ammann 1996; Flintoff 2004; Hau'ofa 2005; Nunns 2014). Moreover, recent research has shown musical instruments to be central to past indigenous technological innovations (Kaeppler 2001; Troutman 2016), just as past instrumental practices have offered both material and musical histories for the Pacific (Diettrich 2011; Moulin 1997; Moyle 1988). In this article I build on these ideas to chart the movements of instruments in 
the late 19th and early 20th centuries, through processes that simultaneously brought innovation and abandonment.

Contemplating historical musical instruments in the Pacific Islands emphasises the fundamental relationship between colonialism and the process of silencing, for as Philip Bohlman (2016: 173) has eloquently declared, "the history of encounter is narrated by silence". Throughout the Pacific and beginning with the earliest cultural engagements with European and American ships, silencing followed-inaudible transformations that give voice to the turbulence of the times. "For it is from the power to silence that the power to colonise and to subjugate eventually comes", adds Bohlman (2016: 173). In Micronesia, not just the voices of instruments but also a plethora of musical practices became gradually muted during the imperialism of the 19th and 20th centuries, a time span that brought Spain (1886-1899), Germany (1899-1914), Japan (1914-1945) and the USA (1945-1976) to the northwest Pacific Islands. As trophies of the sonic transformations that took place in the name of art, technology and exotica, musical instruments were collected for museums and archives that today provide visual evidence of the interplay of sound and silence that moved across the Pacific. Musical instruments held as inaudible artefacts in international collections reveal much about the links between imperial enterprises and the process of silencing. In this article I position the abandonment of flutes in Micronesia as a case study in a larger history of sound and silence in Oceania. But such a history must account for the musical voices that filled the absences, for silencing gives way to sound. As musicians in Micronesia put down their flutes, new technologies were on hand, brought in on ships and initially through whalers, traders and missionaries. Considering the movements and intersections of these instruments speaks to the material and sonic modernities that emerged in the late 19th-century Pacific, a period of simultaneous upheaval and creativity. These spaces of materiality and non-materiality underscore questions of agency for indigenous societies in dynamic, colonial contexts.

For the area of the Pacific called Micronesia, musical instruments - or more precisely a supposed lack of-have been influential in a broader discourse of cultural absence (Diettrich 2011; Rainbird 2003). Absence forms an underlying theme in numerous writings about Micronesian music and instruments, particularly in reports from the colonial powers that administered the islands. Just as commentators lamented the apparent disappearance of island societies, they also judged them for their lack of materials and cultural artefacts. The absence of flutes appears at the nexus of this representational and material nonexistence, as things ephemeral but abandoned during colonial enterprises, and yet preserved as specimens of historical presence. A critical study of this absence reveals instead spaces of movement, of musical possibilities and capacities in the face of colonialism and of transformational shifts in sound and silence. 


\section{Mapping Silence: Historical Flute Practices}

The peoples of Oceania historically produced a great variety of instruments, including numerous types of flutes (Ammann 1996, 2007, 2012; Fischer 1986; Flintoff 2004; Kaeppler 1974; McLean 1968, 1974, 1999; Moyle 1988, 1990a, 1990b; Nunns 2014; Nunns and Thomas 2005; Zemp 1978, 1981). The most comprehensive survey of flutes was part of Fischer's (1986) broad historical study of Oceanic instruments, but as Ammann (2007: 9) has commented, "detailed research on the existence of nose-blown flutes in Micronesia has not been undertaken". Beginning with the periods of colonisation and missionisation, and especially with the acceptance of new musical styles and structures, the peoples within Micronesia gradually discarded many instruments that were previously reported in the 19th century. Past accounts speak of the encroaching silence that followed initial cultural encounters and colonisation, and by the late 20th century indigenous flutes were no longer produced or played across the Caroline Islands, with reports of their past existence linked to a few knowledgeable elders. In order to better understand this silencing as part of instrument circulations and in part to amend the lacuna in musical knowledge for the northwestern Pacific Islands, a close and comparative reading of the historical contexts of these instruments is needed. In the sections below I undertake a mapping of these muted practices that illustrates the acoustic and material impositions that were forged through colonisation. ${ }^{2}$

Mariana Islands. In the Mariana Islands, including the island of Guam, Chamorro constructed and played two types of indigenous flutes until the late 18th century. After centuries of colonisation beginning with the Spanish in the 17th century and early abandonments within cultural and musical transformations, little information is available about these instruments. Historical records mentioned two types of flute both made from bamboo: an end-blown instrument called silag played with the mouth and made with six finger holes and a hole for the thumbs, and a nose flute called bangsi that was held transversely. ${ }^{3}$ According to Freycinet (1824: 399) Chamorro no longer played these flutes at the time of his visit to Guam in 1820, and they seem to be some of the earliest types of flutes to have been discarded in the Pacific Islands (Clement 2001:76).

Eastern and Central Caroline Islands. From the early 19th century and from increased contact with European and American ships, the people of Kosrae underwent decades of social upheaval and population decline, in part from the spread of infectious disease (Gorenflo 1993). The resulting cultural transformations were evident during the visit of Ernst Sarfert in 1910 as part of the Hamburg South Seas Expedition. Without museum examples, images, or sound recordings available, Sarfert's work remains the single, tenuous source for Kosraean musical instruments (1919: 487). ${ }^{4}$ Although Kosraeans had already abandoned flutes and their musics by 1910 , Sarfert 
was able to elicit information from elder men who played the instruments in their youth and who could describe them. Kosraeans apparently called their bamboo flutes nikacruhruh (Sarfert 1919: 487). Unlike the Caroline Islands to the west, elders described a pan flute and what Sarfert calls a mouth flute, but not a nose flute. The only reported case of a pan flute in Micronesia, Kosraeans noted to Sarfert that the instrument had four to eight pipes in a single row. Although Sarfert refers to the second type as a mouth flute, what he describes - a vertical instrument with a carved tongue - was apparently a single-reed aerophone. Sarfert learned that this instrument was fashioned from bamboo, was end-blown, was closed on the blown end and open at the distal end, and had several finger holes. He also recorded that it was played by children, but he added that the sound of the instrument had magical power and thus suggested a greater cultural significance than that implied by a toy (Sarfert 1919: 487). Sarfert speculated that the reed aerophone was imported from European visitors, and while there is precedent for this from a case on Pohnpei (see below), no details have come forward from the historical record. Sarfert also mentioned that Kosraeans imitated European transverse pipes but provides no details. By 1910 there was a clear disruption in knowledge about indigenous instruments on Kosrae, and the silence left behind is reflected in Sarfert's pains to describe the inaudible past.

By the early 20th century flutes were rare on the island of Pohnpei, where people formerly constructed and played distinct types from local materials (Hambruch 1936: 221). By the 19th century Pohnpeians produced the following flutes: (1) an end-blown nose flute called keseng en tumwe (instrument of the nose) that had two finger holes, (2) a side-blown mouth flute called keseng lepin rahu (instrument of reeds) with three or four finger holes and (3) what Hambruch calls a "tongue [lamella] flute" with four finger holes (Hambruch 1936: 223-25; O'Connell 1972 [1836]: 162). ${ }^{5}$ While the earliest writers consistently cited only a nose flute on the island (Cheyne 1971 [1841-44]: 188; Finsch 1893: 243; O’Connell 1972 [1836]: 161; Scherzer 1862: 584), the side-blown mouth flute was only mentioned by visitors near the end of the 19th century (Cabeza Pereiro 1895: 130; Christian 1899: 298), and this perhaps points to its introduction through European visitors. Finsch (1893: 243) reported and collected a different type of nose flute for Pohnpei than those described in early reports, and this instrument is now held in the Museum für Völkerkunde at the Weltmuseum in Vienna (see Diettrich forthcoming). This type of long nose flute is similar to a type commonly played in Chuuk, as described below. The "tongue flute" reported by Hambruch is a single-reed aerophone, an instrument also reported for Kosrae and elsewhere in Polynesia; nothing else is known about it in Micronesia. Pohnpeians constructed these melodic instruments from bamboo (pehri), grown widely on the island, but they also used the reed rahu (Phragmites karka) (Hambruch 1936: 223). Hambruch's (1936: 223) published sketches of the nose and mouth flutes and 
the single-reed aerophone provide the best illustrations of these instruments. In addition to the reports from Pohnpei, Eilers (1934: 396) reported the name of a nose flute (gaseng) for the outer island of Mwoakilloa.

In the islands of Chuuk Lagoon and its surrounding atolls people played nose flutes called aangún and sometimes named with the more general term áttik or nikattik (sound-producer). The men of Chuuk constructed nose flutes from bamboo or mangrove root and of two types: one short with finger holes and the other long without finger holes (Bollig 1927: 240; Damm and Sarfert 1935: 263; Finsch 1893: 311; Krämer 1932: 384, Plate 17, 1935: Plate 23; Kubary 1889: 61; LeBar 1964: 383-84; Tanabe 1935, 1968). On the atoll communities surrounding Chuuk people historically played nose flutes similar to those of the lagoon, with reports of flutes from the Mortlock Islands called anin or atik (Girschner 1912: 166; Krämer 1935: 130) and from Pollap Island (Krämer 1935: 286), as well as from Polowat (called anin) and Houk (called ligatik) (Damm and Sarfert 1935: 263). Flute players from Chuuk recorded their music into the phonograph of Augustin Krämer in 1907 in what are the only sound examples of these instruments (Krämer 1932: 395, 402-3; Ziegler 2006: 383). The nose flutes from Chuuk are the most representative of Micronesian flutes in international museum collections, perhaps indicating the popularity of their past use.

People played flutes on at least some of the central Caroline atolls that are scattered between Chuuk and Yap and to the southwest of Yap. German researchers for the Hamburg Expedition reported a nose flute of bamboo called janil on Satawal Island (Damm and Sarfert 1935: 264), a nose flute of bamboo called tigetig and collected by Helwig (Krämer 1937: 175) from Lamotrek Island, and a flute from Tobi called fasafasarien (Eilers 1936: 113). Little else is known of these instruments, and the German expedition was apparently the last to document their usage.

Western Caroline Islands. On Yap a bamboo flute played in the early 20th century was called ngael (Born 1903: 134; Haas 1906: 138; Müller 1917: 203). The instrument was end-blown from the mouth, and historical reports do not describe a nose-blown instrument for Yap. The Yapese ngael had four finger holes and was played with an external duct. By all accounts the Yapese flute was more or less identical with the instrument made on Palau, a connection that stemmed from the close cultural associations between both areas. Haas (1906: 138) wrote that "the flute produces a very soft and sensually tender sound and, indeed, serves less for actual musical entertainment than for communication between lovers", ${ }^{6}$ According to Müller (1917: 203), by 1910 Yapese had considered the ngael as a toy. One Yapese man, unnamed, recorded a melody on the ngael for the phonograph of Krämer in 1907 (Herzog 1936: 298; Ziegler 2006: 383), and this is the only such sound document in existence.

The people of Palau (Belau) formerly played an end-blown bamboo mouth flute called ngaok that was almost identical to the Yapese ngael (Abels 2008: 
67-73; Krämer 1926: 319; Semper 1873; Yamaguchi 1967: 55-57). This flute was actively played in the late 19th century (Semper 1873), and unlike reports of other flutes, both men and women played the ngaok, with women playing in the contexts of the men's clubhouse. Palauan men played the ngaok into the phonograph of Siemer in 1936 and into the microphone of Smith in 1963. Smith recorded the flute played by Ucherbelau Ngirubekbad, one of the last knowledgeable Palauans who could do so. ${ }^{7}$ For the island of Tobi (Hatohobei) that lies southwest of Palau, Eilers (1936: 113) reported a bamboo flute of unknown type documented by the Hamburg Expedition in 1909.

The mapping of flutes in Micronesia, and especially within the Caroline Islands, demonstrates a variety of flute types - both mouth- and nose-blownthat were formerly constructed and played (Table 1). Tracing reports of these instruments and their practices through time, and notwithstanding the limited information available for some island areas, reveals a gradual abandonment of flutes from the 19th century, with the last reports of players from Chuuk and Palau in the mid-20th century. For Chuuk detailed archival documentation is supported by numerous flutes in museums and some oral history, and together this data provides material and contextual information about the aangún. In the remainder of this study I first explore the Chuukese aangún as a focused case study of one flute type from Micronesia, and second, I examine the discarding of flutes within the circulation of colonial instruments and musics from the late 19th century.

Table 1. Historical flutes from the Mariana and Caroline Islands.

\begin{tabular}{llll}
\hline Place & Name & Type & Material \\
\hline Mariana Is. & $\begin{array}{l}\text { silag } \\
\text { bangsi }\end{array}$ & $\begin{array}{l}\text { mouth, end-blown } \\
\text { nose, side-blown }\end{array}$ & $\begin{array}{l}\text { bamboo } \\
\text { bamboo }\end{array}$ \\
Kosrae & nikacruhruh & panpipe/reed aerophone & bamboo \\
Pohnpei & keseng en tumwe & nose, end-blown & bamboo, reed \\
& keseng lepin rahu & mouth, side-blown & bamboo, reed \\
Mwoakilloa & gaseng & nose & unknown \\
Chuuk & aangún & nose, end- \& side-blown & bamboo, mangrove \\
Mortlock Is. & atik & nose, end- \& side-blown & bamboo \\
Satawal & janil & nose, end-blown & bamboo \\
Woleai & tigetig & nose & bamboo \\
Yap & ngael & mouth, end-blown & bamboo \\
Palau & ngaok & mouth, end-blown & bamboo \\
Tobi & fasafasarien & unknown & bamboo \\
\hline
\end{tabular}




\section{PART II. INTIMATE SOUNDS}

\section{Materiality and Nose Flutes in Chuuk}

Musical instruments are closely linked to place through their material qualities, and thus a beginning to the study of the aangún is an examination of its rootedness and thus its history in the environment of Chuuk. The resources of Chuuk's numerous islands (including its surrounding atolls) and its seas have been used in making sound instruments, but it was bamboo and mangrove wood that Chuukese exploited for flute manufacture. Common bamboo (Bambusa vulgaris) is known as iich in Chuuk, and it grows in the cultivated agroforests of the lagoon's high islands. Using stalks of the plant Chuukese men also carved mouth harps (or jew's harps) called fillipwow or tinipwow, and long dance staves that were a substitute for a hardwood type. Compared with bamboo, mangrove trees, known generally as chiya in Chuuk, have a much larger role in the ecosystem of the islands. Mangroves grow in the saltwater swamps surrounding the high islands and form a liminal environment between land and the shallow sea beyond. Of two general types of mangroves found in Chuuk, it was those with soft and porous hanging aerial roots (chiyaan iimw or chiyaan wuumw) that extend from under the water to the trunk well above that Chuukese hollowed out and dried for flutes (Merlin and Juvik 1996). Although not immediately as resonant as bamboo, they nevertheless serve as an efficient material to convey sound.

In the late 19th and early 20th centuries both mangrove and bamboo served as valued musical materials with which Chuukese men constructed two distinct types of nose flutes. One type was an end-blown flute without finger holes and made from a long single piece of bamboo or mangrove root. It was open at the distal end but at the playing end it was fit with a plug that had a hole bored into it to direct the air column from the nose. The second type, also made from mangrove or bamboo, was a shorter instrument, also open at the distal end, and apparently end-blown using a plug or possibly with the hole bored into the bamboo node; it had one to three finger holes in the lower half of the instrument. Two photographs of nose flute players from Krämer's publications on Chuuk (Krämer 1932: Plate 17, 1935: Plate 23) show the two types of flute and the playing position of each (Figs 1 and 2). Tanabe (1968: 55) also provides a photograph of a Chuukese man playing the long type of nose flute. The flutes held in international collections as well as those described in the ethnographic literature are mostly of the longer flute type without finger holes, perhaps indicating that this type may have been used more widely by the late 19th century.

The short nose flute (Figure 3) is similar to a type reported on Pohnpei, and except for its possible end-blown form, this type of nose flute is also similar to that of eastern Polynesia (Moyle 1990a). Fischer documented 


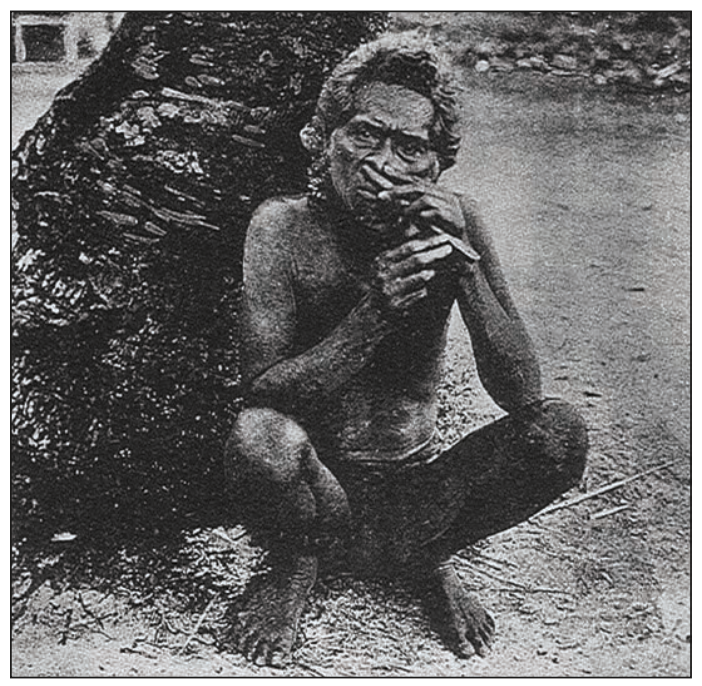

Figure 1. A man from Chuuk playing a short nose flute in 1907 (courtesy of the Micronesian Seminar Library, Chuuk, Micronesia).

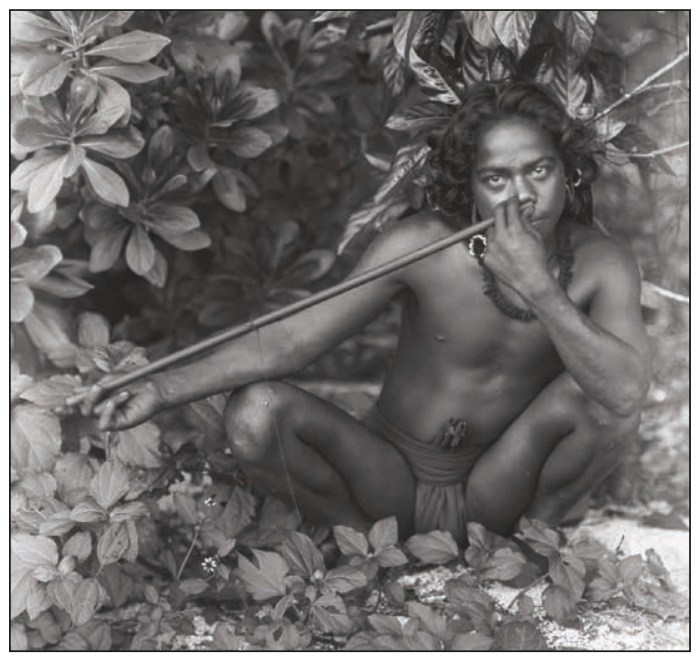

Figure 2. Haliong from Pollap Island playing a long overtone nose flute in 1907 (courtesy of the Museum für Völkerkunde, Hamburg, Germany). 
and sketched two short nose flutes that he attributed to the card catalogue of the Museum für Völkerkunde, and that were originally collected from the Mortlock Islands, south of Chuuk Lagoon (1986: 202-3). At the time of writing I have not been able to confirm these instruments, but the sketches by Fischer show nose flutes similar to the example illustrated in Figure 3; flute 968:05 is $18 \mathrm{~cm}$ in length with one sound hole, and flute 969:05 is 19 $\mathrm{cm}$ in length with three sound holes (Fischer 1986: 202-3).

The long nose flute without finger holes (Fig. 4) has not been previously documented in detail for Oceania. Technically an overtone flute, this long instrument appears to be the sole representative of this type of nose flute in the Pacific Islands. ${ }^{8}$ This flute required a separate piece of material with a hole in it that was inserted directly into the blowing end and that directed the airstream from the nose. Tanabe (1968: 54) reported that this separate piece was made from coconut wood, while LeBar mentioned coconut meat:

A straight section of root about 3 feet long is selected and the outer bark cut away for a few inches in from either end. The pithy core is removed by twisting, leaving a hollow shell of mangrove bark. A flat, circular piece of coconut meat with a small hole through the center is then inserted at one end of the bark tube. The meat becomes hard on exposure to the air. (LeBar 1964: 383-84)

The player changed pitch by overblowing and produced two separate series of tones, one with the pipe open and the other with the pipe stopped at the distal end with a finger. According to LeBar (1964: 383), the instrument "is held out to the right of the player, the left index finger pressing on the right nostril, thus forcing the air through the left nostril". Using these two series of tones, this instrument had a more extended range than the shorter type of nose flute with finger holes (Tanabe 1968). Additionally, the technique of overblowing with the nose required technical proficiency and some practice.

The only available sound recordings of the aangún, all made by Krämer in 1907, demonstrate the music of both the long and short types of nose flute, and thus show the melodic differences between both instruments. The two recorded examples of the overtone flute both illustrate a melodic range of over an octave (Herzog 1932: 402-3), while the range of the shorter flute is limited and encompasses three tones (Herzog 1932: 395). These two very different instruments afforded players two contrasting approaches to melody and musical practices more broadly.

The aangún was an intimate instrument, through the process of its construction and playing, and in its social contexts. The process of making the flute required time in drying the material and for the longer type, skill in fashioning the plug. From the perspective of the player the two types required 

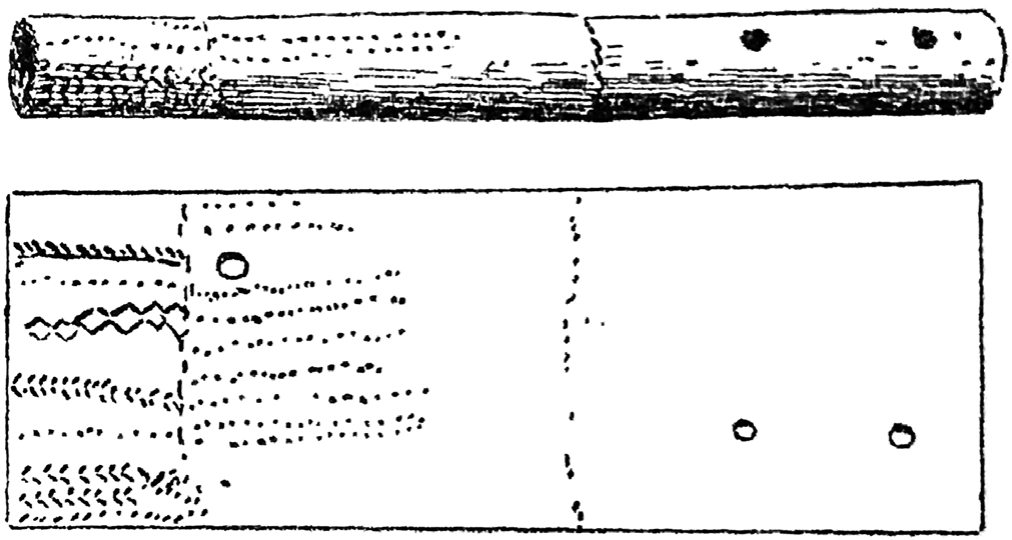

Figure 3. A short Chuukese nose flute from 1907 and showing sound holes (courtesy of the Micronesian Seminar Library, Chuuk, Micronesia).

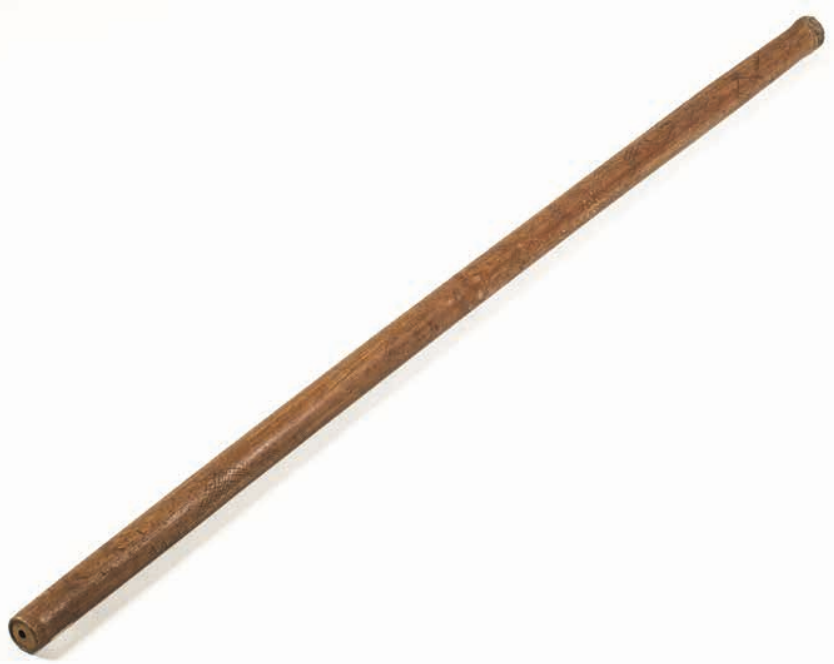

Figure 4. A long Chuukese nose flute made from bamboo, item E138.896 in the Canterbury Museum, dates from 1895 or 1896 (courtesy of the Canterbury Museum, Christchurch, New Zealand). 
both hands with the instrument held close against the face to accept the airstream from the nose. Further practice and gauging was needed with any new instrument as each was different and required time to produce a resonant sound, especially using the longer flute that required skill in overblowing with air from the nose to achieve different tones. The breath from the nose was clearly valued for its distinctive qualities. Tanabe (1968: 53) noted a Chuukese comment that "the mouth exists for eating food and the nose exists for breathing". Indeed, the quiet sound of the flute, recorded in its suggestive name, is a result of the use of the nose. Played with one nostril blocked but with less air pressure than from the mouth, the flute produced a soft, slightly breathy sound from its acoustic properties, due to its long resonating chamber but especially from its exploitation of the upper harmonics of the overtone series. Beyond its sound quality the intimacy of the flute was associated with its performance contexts.

\section{The Nocturnal Lives of Nose Flutes}

\section{A soft melody played upon a nose flute outside a girl's house was both a serenade and an invitation (Gladwin and Sarason 1953:104)}

The Chuukese aangún was made by men who played favourite melodies, especially those from the genre of love chants called engi. The social interactions that surrounded nose flute playing, however, were more significant than the flute's tunes alone. Rather it was sounded for nocturnal courting and thus closely associated with sexuality (Goodenough 2002: 252). This explains the comments of Catholic missionary Bollig (1927: 240) who condemned the flute because it did not "have a good reputation", and he referred to it as an "instrument of licentiousness". Tanabe provided more details about the playing context of the flute:

The nose flute is performed only by men; women do not play it. When a man goes to the house of the woman he loves and plays the nose flute quietly, the woman who hears it recognizes the player. If she does not like the man, she ignores it, and if she likes the player, she tiptoes out of the house and disappears with the man into the palm forest in the mountain. In other words, the nose flute is used for calling a woman out. (Tanabe 1968: 56)

The association of the flute with courting is one of the few threads of oral history that is still linked to the instrument by a few Chuukese elders. For example, in 2001 the late Meichik Amon of Toleisom in the western islands of Chuuk identified to me one of Krämer's 1907 recordings of the aangún as music for kamwmwet (sweetheart or lover) and explained that the flute was played as a means to communicate in secret. 
As an instrument of communication and expression the nose flute was interwoven into a complex Chuukese aesthetic associated with nocturnal affairs and especially with the practices of itenipwin (serenading) and also tééfán (house crawling), avenues of courtship and sexuality (Goodenough 2002: 251-52; Moral 2002). As such, the use of the nose flute was aligned with practices recorded about the Chuukese courting stick (fánáy), known as the "love stick" in English and which provides some further context for the flute. Men apparently used these individual carved, slender spears of wood as a means of identity, and as the stories today relate, they apparently used them to awaken a woman surreptitiously in the night by inserting one into the thatch of her home (Goodenough 2002: 252; LeBar 1964: 180).Underpinning the practice is a strong aesthetic of concealment in the various means by which individuals conduct affairs and communicate covertly. The playing of the nose flute was evidently another means of this disguised communication between lovers, a context also recorded for flutes not only for Chuuk but elsewhere in Micronesia and the Pacific Islands. ${ }^{9}$ The melody of the nose flute communicated a quiet, sonic message that personally identified the player. Tanabe accordingly wrote, "the islanders play their own unique melodies (or rather motifs), so women can identify who is playing the flute even in the dark of night. That is why the nose flute is often used at night to invite out one's beloved woman" (Tanabe 1968: 47).

The music played on the nose flute comprised the tunes of engi, a genre of lament for unrequited love (LeBar 1964: 384 ). ${ }^{10}$ It is unclear exactly how players performed instrumental versions of these chants. Engi and older forms of love songs (kéénún núkún) exhibit expressive and ornate styles of melody that Chuukese associate with the emotional character of music and its sentiments. This melodic practice is also heard in the two recorded melodies of the larger aangún from 1907. These cultural and musical underpinnings further characterised nose flute playing in Chuuk as a deeply personal and private activity that played an important role in individual relationships. Nose flutes must have been especially intimate instruments for both players and listeners, their soft reverberations closely linked with clandestine, nocturnal practices outside of the public gaze.

As visual artefacts the surviving examples of aangún in international collections are mostly undecorated lengths of cane, but with two important exceptions. The first example is a flute sketched in Damm and Sarfert's volume on the islands surrounding Chuuk (Damm and Sarfert 1935: 263). In their brief description of music the authors include a sketch of a nose flute from Polowat, item 2366 in the Hamburg Museum at the time of the original publication. Along the length of the $74 \mathrm{~cm}$ flute are incised characters of the Caroline Island or Woleai script, a syllabary devised in the Caroline Islands from the influence of Protestant missionary-taught writing in Chuuk in the late 


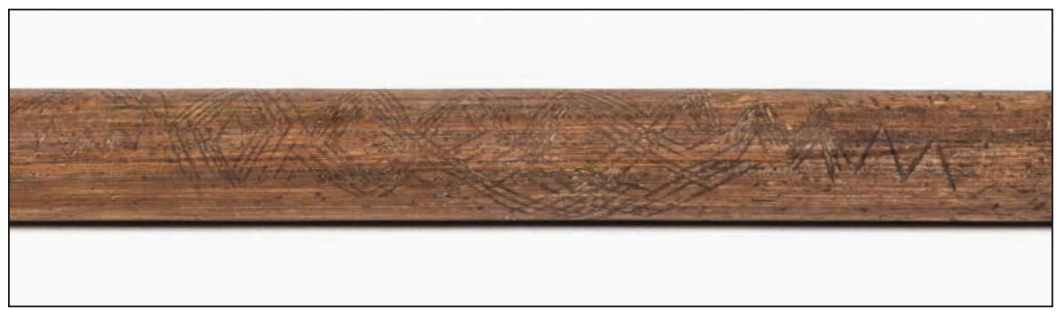

Figure 5. Detail of incised design on nose flute E138.896 from 1895 or 1896 and held at the Canterbury Museum (courtesy of the Canterbury Museum, Christchurch, New Zealand).

19th century (Brown 1914; Riesenberg and Kaneshiro 1960). It is likely then that the maker or someone else incised this flute with a personalised message. The second example is a nose flute collected by amateur British naturalist Alan Owston (1853-1915) in Chuuk in 1895 or 1896. This flute, now item E138.896 in the Canterbury Museum, was overlaid with detailed incised decorations down the full length of the flute and which comprised triangular patterns, crossed lines, angular motifs and diamond shapes (Fig. 5) - nuanced details similar to Chuukese visual designs documented by Krämer (1932: 113-14). Clearly the construction and imagery of this instrument was a work of some contemplation, its personal and sonic qualities amplified through its visual intricacies. These two examples of flute decoration offer further visual evidence for the personal and intimate contexts of the aangún in the late 19 th and early 20 th centuries. ${ }^{11}$

\section{PART III. INSTRUMENTS IN MOTION}

Flute Movements, 1879-1947

There is hardly anyone left, if anyone at all, who knows how to play the nose flute (Fischer and Fischer 1957: 203)

Scholars of materiality have come to explore more fully the movements and pathways of things and their intersections with humans (Hahn and Weiss 2013; Hodder 2011; Joyce and Gillespie 2015). This attention to motion has shifted our understanding of materials and things from sedentary to dynamic, and it further emphasises the role of things in their complex "meshwork" of relationships (Ingold 2012; Joyce and Gillespie 2015).Viewing things through unfolding movements in time and across space also provides an alternative to ubiquitous frameworks of encounter that, although usefully 
situate cross-cultural engagements with Pacific artefacts, have nevertheless tended to echo pervasive contact narratives for the Pacific. ${ }^{12}$ Understanding instruments in motion, rather, offers insights into the everyday material and musical circulations that took place in Micronesia during the late 19th and early 20th centuries, in which newly appropriated musical things travelled locally, just as Micronesian things moved internationally through channels of scientific and archival collection.

In late 19th-century Chuuk musicians played nose flutes alongside the instruments that arrived in the islands on ships. They incorporated these novel instruments - harmonicas, accordions and metal jew's harps - into their social and musical lives, and these quickly became part of the sonic fabric of village life. Underpinning these circulations were new materialities as well as emerging musical structures, some decreed by missionaries and others brought by traders and other visitors. Simultaneously, foreign collectors and other visitors deemed local musical instruments as valued exotica, visual trophies of primitive expressions and of disappearing cultures to be displayed in museums. Flutes played with the nose presented strikingly novel artefacts for acquisition in international collections, and the nose flutes of Micronesia would have reminded some collectors of the more well-known examples from Polynesia. Chuukese nose flutes moved internationally at the same time that men at home in Chuuk put down their flutes and looked to new modes of expression.

The first nose flutes obtained from Chuukese musicians for an international collection were those acquired by Johann Stanislaus Kubary (1846-1896), an ethnologist and collector for the Godeffroy Company before its closing. Kubary resided in Chuuk from May 1878 to August 1879 and visited again in 1885 aboard the Albatross, and he was apparently the first to publish on the existence of Chuukese flutes (1889). In 1879 and over the course of his longest stay, Kubary acquired two bamboo flutes that are now held in Leipzig at the Museum für Völkerkunde, though the exact island of their origin in Chuuk is not known (Schmeltz and Krause 1881). Missionaries also had a role in transporting flutes to museums as artefacts of the very heathenism that they battled against. Such a case is the pair of long mangrove flutes without finger holes that now reside in the Bernice P. Bishop Museum in Honolulu and designated as $\mathrm{C} 3448$ and $\mathrm{C} 3450 .{ }^{13}$ These instruments were received in Honolulu by Joseph Swift Emerson, who credited their acquisition in Chuuk to Arthur Logan (Evans 1974), the young 16-year-old son of missionaries Robert and Mary Logan of the American Board of Commissioners of Foreign Missions (ABCFM), and the first American missionaries to reside in Chuuk. As part of early 20th-century salvage research, the Hamburg Expedition sought out and obtained Micronesian flutes and other instruments, and also 
represented musical practices in audio and visual media. In still another example, the musical qualities of the aangún led early Japanese music researcher Hisao Tanabe to learn to play the flute from a young man from Tonoas Island in 1934. Tanabe later brought three Chuukese nose flutes to Japan, and remarkably, he played one of them in person on a hobby radio programme on NHK, Japanese National Public Broadcasting. This was a singular instance of a performance of the aangún outside of Micronesia to an international radio audience (Tanabe 1968). Table 2 presents examples of 15 Chuukese nose flutes currently held in collections internationally, and each holds its own itinerary of movement (Joyce and Gillespie 2015).

Table 2. Fifteen nose flutes from Chuuk and its outer islands in international collections.

\begin{tabular}{|llllll|}
\hline Date & Origin & Designation & Museum & Collector & $\begin{array}{c}\text { Length } \\
\text { (cm) }\end{array}$ \\
\hline 1879 & Chuuk & Mi1872 & Leipzig & Kubary & 73.0 \\
1879 & Chuuk & Mi1873 & Leipzig & Kubary & 68.5 \\
1887 & Weno Is. & C3448 & Honolulu & A. Logan & 81.2 \\
1887 & Weno Is. & C3450 & Honolulu & A. Logan & 80.6 \\
pre-1891 & Mortlock Is. & $828-74$ & Leiden & Brandt (?) & 84.0 \\
$1895-96$ & Chuuk & E138.896 & Christchurch & Owston & 70.5 \\
1899 & Weno Is. (?) & E206354-0 & Washington & H.F. Moore & 81.3 \\
1909 & Polowat Is. & Mi 3907 & Leipzig & Hamburg Expd. & 51.8 \\
1909 & Polowat Is. & Mi 3098 & Leipzig & Hamburg Expd. & 69.7 \\
1910 & Chuuk (?) & Mi 3516 & Leipzig & Lorensen & 68.5 \\
$1909(?)$ & Caroline Is. & $2001-56$ & St Petersburg & Hamburg Expd. & 60.5 \\
$1909(?)$ & Caroline Is. & $2001-57$ & St Petersburg & Hamburg Expd. & 64.3 \\
$1909(?)$ & Polowat Is. & $2001-16$ & St Petersburg & Hamburg Expd. & 55.8 \\
1936 & Chuuk & C8656 & Honolulu & Bishop Museum & 84.2 \\
acq. 1975 & Chuuk & K0000437 & Osaka & Tanabe (?) & 69.0 \\
\hline
\end{tabular}

While nose flutes were prized personal instruments in Chuuk, by the early 20th century they also represented increasingly specialised practices in an expanding world of musical styles and material things. Chuukese gradually sang less from the musical structures of engi and instead favoured newly 
created love songs, with tunes and harmonies variously drawn from church hymns, Japanese school songs and popular musics. The first published reference to the possible abandonment of the aangún came from Namoluk Island, an atoll south of Chuuk Lagoon, and where Girschner (1912: 166) reported that the harmonica and jew's harp were popular instruments just as the nose flute was increasingly rare. Evidence of the widespread abandonment of the flute came with the American publications and reports from Chuuk that appeared after World War II. Gladwin, for example, noted that the harmonica had taken over the serenading function of the flute in the preceding decades (Gladwin and Sarason 1953: 104). Additionally, Jack and Anne Fischer wrote in their postwar handbook on the Caroline Islands:

The few native musical instruments are now obsolete or nearly so and are replaced by the guitar, harmonica, and ukulele ... As such it [the nose flute] was a target for missionary prohibition, although perhaps a more important factor in its disappearance was the great popularity of Western music and introduced instruments. (Fischer and Fischer 1957: 203)

The Fischers suggest the importance of musical choices and new acoustic possibilities in the islands, and that were evident by the $1950 \mathrm{~s}$, in the discarding of former instruments. Although they hint also at the role of missionaries, the vast archive of ABCFM missionary letters contains scant evidence of a direct missionary silencing of nose flutes, though in the new Christian morality that the ABCFM promulgated, nose flute practice and its associated contexts in clandestine affairs would have been viewed negatively. Having conducted research from 1947 to 1948, LeBar was the last to mention the Chuukese nose flute, writing cryptically that it could still be found but without information on players or contexts (1964: 383-84). Into the cultural and musical vacuum from discarded flutes - and, as I suggest, assisting to create these spaces - were new instruments, new musics and novel opportunities. It is to these musical and material pathways that I now turn.

\section{New Instruments in Colonial Circuits}

European musical instruments, such as the accordion and harmonica, are widespread on the islands and are often played very well (Bollig 1927: 240)

In their material and musical forms instruments have always been moving technologies that challenge our understanding of the past beyond simple binaries of tradition and modernity. For example, in a useful study, Kaeppler (2001) has examined the integration of accordions into Tahitian performance as an indicator of "musical modernity", while Troutman (2016: 10-30) has 
explored the Hawaiian steel guitar as a means of indigenous innovation and experimentation in the cultural landscape of the American overthrow of the Hawaiian Kingdom. Instruments are intricately linked to colonisation, for just as imperialism brought new silences, so too did it offer new resonances, for example in the sounds of military bands and instruments of religious service. In the martial-laden metaphors of 19th-century missionisation in Micronesia, sound instruments were not simply forms of entertainment or communication: they were powerful tools in the battles for souls and salvation. On Weno Island in Chuuk in 1885, for example, ABCFM missionaries made special mention of a new church bell from California that resounded for the first time across the village of Mwáán in March or April of that year, and by which they replaced the shell trumpet that they previously, and perhaps reluctantly, used until then (Logan, 8 April 1885). For the American missionaries this new instrument that rang out in Chuuk for the first time was not merely a call to service, but a technology bearing civilisation itself in its tuned, metallic resonance. The impact of instruments in the colonial Pacific is inclusive of a sensorial world that is broader than audible culture alone, as instruments ushered in new material, visual, technological and social relationships. Such pathways in the meshwork of Pacific experiences (Ingold 2012) sit alongside of and challenge stark narratives of indigenous cultural vanishings. Accounts of instrumental innovation provide a more nuanced reading of colonial pasts and illustrate how in the wake of imperial silencing, some Pacific Island musicians adapted and re-imagined cultural and expressive possibilities.

Most of the musical instruments that made their way from Europe and America to the Caroline Islands by ship in the 19th century were small and portable, and they included accordions and harmonicas (both free-reed aerophones), as well as jew's harps (lamellophones) made from metal. The accordion and the harmonica originated with German-speaking manufacturers in the early and mid-19th century, and due in part to their portability, both instruments were played on board ships. They became closely linked with maritime culture and were eventually incorporated into numerous global and indigenous music cultures (Beynon 2017; Harrington and Kubik 2017). Jew's harps have an older history globally, but their small size and portability also meant that they were brought on ships and were used as trade items in the 19th century (Wright 2011, 2017). Islanders likely perceived metal jew's harps as more of a material transition than a new instrument, with bamboo jew's harps fashioned and played in the area of Micronesia. Each of these instruments were introduced at different times variously by whalers, traders, beachcombers and missionaries from the mid-to-late 19th century, but direct information about their earliest movements and usage is limited in historical accounts. 
The island of Pohnpei to the east of Chuuk, however, held a sustained traffic of traders and missionaries in the mid-to-late 19th century, and we therefore have a frequency of reporting about these same instruments on the island that is a useful case example for comparison. Writing about Pohnpei from the early 1840 s, for example, trader Andrew Cheyne was one of the first to mention the importation of new instruments to the island; he noted: "The description of goods which are most sought after by the natives ... [included] jew's harps" (Cheyne 1971: 173-74). By 1871 Pohnpeians had such an understanding of new instruments that a crew member aboard the bark John Wells sold an accordion to one of the district chiefs (Ransom 1871). Likewise, writing from his 1887-91 experiences with the Spanish administration, Cabeza Pereiro (1895: 124) noted that it was rare to find a home without an accordion and commented on its incorporation into dance, and in 1887, during the Pohnpeian uprising, the Spanish government noted that among the colonial items confiscated by the islanders were two small accordions (de la Concha 1887). Toward the close of the 19th century, an anonymous Spanish naval officer noted in 1890 that five pianos were present on the island (El Comercio of Manila 1890), and Christian (1899: 299) reported on the popularity of both the accordion and the jew's harp.

Similar reports of new instruments were lodged for elsewhere in the Caroline Islands. On the outer atoll of Pingelap, for example, the crew of the German ship Albatross noted in 1885 that harmonicas were a major trade item on the island (Plüddemann 1886). To the east on Kosrae, people began applying the name for the flute (nikacruhruh) to the harmonica after it was introduced in the 19th century (Lee 1976: 83), thus implying a close linkage between the two instruments. On Kapingamarangi atoll the Hamburg Expedition of 1910 found that harmonicas and jew's harps were popular on the island (Eilers 1934: 140), and farther west on Yap, Haas (1906: 47) wrote of the Yapese fondness for harmonicas. All together these scattered reports point to the fairly sustained adoption of new instruments during 19th-century colonial administrations of Micronesia that was simultaneous with the largescale abandonment of cane flutes in these areas.

In Chuuk the individuals who forged new musical possibilities within the colonial instrumental circuits were very likely those who also played nose flutes and who heard new capacities for expression in introduced musical practices, similar to the vocal music examples recorded by Tanabe in 1934 (Tanabe 1978). By the 1880s foreign traders and missionaries, along with islanders who worked alongside them, were active in Chuuk's islands, including prominent Germans such as Frederick Narruhn and later Charles Gierow (Hezel 1995: 66-67). At this time imported goods of clothing and food were increasingly valuable, and from these interactions novel musical 
instruments would have been increasingly visible and audible from the foreign traffic and growing interest in new sacred and secular musics. From his residence in Chuuk (1913-1919) the Catholic priest Bollig (1927: 240) reported that "European musical instruments, such as the accordion and harmonica, are widespread on the islands and are often played very well"an indication of their acceptance by the early 20th century. Demonstrating the integration of the kuchuyen (accordion) into Chuukese aesthetics, Bollig (1927: 242) transcribed a Chuukese song that mentioned the instrument as well as the newly incorporated ideas about music, shown in excerpt below:

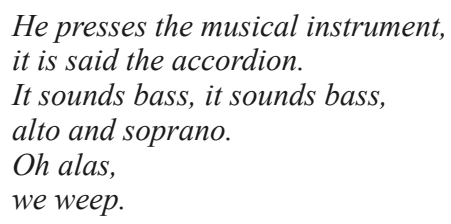

Accordions and harmonicas are well remembered by middle-aged and older Chuukese musicians, who in many cases recall playing them and their musical contexts from their youth and early adult lives. From these oral histories, it is clear that both instruments held prominent musical roles and cultural associations in secular and sacred musics. Due to their diatonic tuning, the harmonica and the accordion were compatible with Christian hymn-singing and imported secular songs, and they became associated with these musics. Today it is rare to find these instruments actively played in Chuuk. Much like the nose flute before them, harmonicas and accordions followed transient pathways in the mid-20th century, when later generations of musicians looked toward the guitar (kitar), the ukulele, and eventually the electronic keyboard for musical and social expression (Diettrich et al. 2011: 124-28). Oral histories among older musicians in Chuuk point to the incorporation of additional instruments over the 20th century such as the oroken (organ), rapwapwa (bugle), mandolin and piano. Further research is required to explore the roles of these instruments and others in the social and musical lives of colonial Micronesia.

In Chuuk the harmonica stands out for its prominent historical role in music. Following the social contexts of the nose flute, Chuukese incorporated the sounds of the harmonica, named muusik in Chuuk, to play favourite love songs. Indeed the name muusik suggests that perhaps the harmonica and its reedy sounds were taken as an early representative example of the introduced Western concept of music into the islands of Chuuk. The harmonica was portable, like the aangún, but it was also more permanent in its physical materiality, and its sound could be learned relatively easily, compared to the more unpredictable open tube of cane. During the first half of the 20th 
century musicians developed the sound of the harmonica into new musical repertories, such as nawen chinnap (coughing of the old) and keenun piruumw (song of the broom), also called piruumwen nukun imwen kamwmwet (broom for the outside of the sweetheart's house) (Goodenough 2002: 260). The wordless love songs that were played on harmonica had their precedent in the love chants (engi) sounded on the aangún. In adopting the harmonica and its musical structures, Chuukese continued the practice of instrumental music in intimate relationships. For example elders in Chuuk have recalled to me stories about harmonica serenading heard in villages both during the night and at dawn, signalling the instrument's role in courtship, much like that documented for the nose flute. But the harmonica also gained a wider usage, for entertainment as an accompanying instrument for marching dances (maas), and by the 1960s as an integral instrumental part within small string bands that performed love songs (Diettrich and Smith 2005).The adoption of the harmonica was not simply an appropriation of sonic novelty, but in learning to play it, and in creating new practices, Chuukese musicians forged new aesthetics and imaginative pathways.

\section{REFLECTIONS}

In this study I have begun to trace the movements of musical instruments within the historical circumstances of the northwest Pacific Islands. Examining indigenous practices of flute playing and the instruments themselves provides insights into the social, material and musical lives of late 19th- and early 20th-century Micronesia, a period of cultural upheaval that brought the silencing of some instruments and musical forms just as it allowed for new creative practices and possibilities. Through the case of flutes and new colonial-derived instruments I have attempted to address how we might critically understand the large-scale unfolding and interplay of sound and silence in imperial circumstances of the Pacific. The case of Micronesia with its multiple colonial entanglements illustrates the usefulness of frameworks of material motion, within the realities of an indigenous modernity that was heard, seen and created by musicians and listeners.

In his writings on the ecology of materials, Ingold explored materiality as a process of becoming when he wrote that "... paths of movement and lines of flow do not connect. They are not between one pre-existing entity and another but perpetually on the threshold of emergence. They are the lines along which materials flow and bodies move" (Ingold 2012). Ingold views this continual unfolding as the basis for the "meshwork" that situates the interplay of materials and forces, and as such, I suggest these ideas have bearing on how we critically understand musical and material expressions. The case of Chuuk in particular reveals the interplay of localised and newly adopted instruments and the capacities of new expressive forms. Thus harmonicas 
and their musics emerged in the colonial period from increased possibilities of expression, as did later incorporations of string instruments and eventually electronic and digital instruments. From this perspective instruments might be usefully compared to the capacities and becoming in sound technology, for example in the historical use of open-reel and cassette-tape recording in Micronesia (as globally) that faded with the arrival of compact discs, music on cell phones and online formats. I suggest in this study that this material motion runs alongside aesthetic choices of expression: knots of emergence that further underpin a local historical consciousness of adaptation, accommodation and renewal, and incorporation within existing cultural preferences. These patterns of emergence offer significant insights into how we might approach the discarding of cultural practices and the simultaneous acceptance of others. Considering the dynamic motion of musical instruments brings attention to the interplay of sound and silence across Pacific pasts and presents.

\section{ACKNOWLEDGEMENTS}

My research into Micronesian instruments has benefitted from conversations and assistance with numerous individuals and institutions over many years. I first thank friends and colleagues in the FSM and especially in the states of Chuuk and Pohnpei for previous discussions about music, instruments and the past. More recently and in the preparation of this article I thank Don Niles, Raymond Ammann, Michael Clement, Barbara Smith and Jane Moulin for correspondences about Oceanic flutes, and Mac Marshall about Chuukese terminology. In assisting with information on Micronesian flutes held internationally for this study I gratefully acknowledge the help of Hilke Thode-Arora (Staatliches Museum für Völkerkunde, Munich), Sijbrand de Rooij and Wonu Veys (Museum Volkenkunde, Leiden), Marion MelkKoch (Grassi Museum für Völkerkunde, Leipzig), Gabriele Weiss (Weltmuseum Wien), Hatesa Seumanutafa (Canterbury Museum, Christchurch), Manami Aoki (National Museum of Ethnology, Osaka), Adrienne Kaeppler and Carrie Beauchamp (Smithsonian Institute, Washington), and the Bernice P. Bishop Museum (Honolulu) for an earlier period of investigation. My research has been supported previously by the University of Hawai' $i$ at Mānoa, the Wenner-Gren Foundation, Victoria University of Wellington and the Faculty of Humanities and Social Sciences, and the College of Micronesia-FSM.

\section{NOTES}

1. There has been a sustained scholarly debate about the usage of the term Micronesia (Hanlon 2009; Petersen 2009; Rainbird 2003), and as a result I employ the term cautiously and with an awareness of its colonial origins. My usage of Micronesia does not suggest a culturally bounded or unified area, but instead I attempt to redress cultural information about the northwest Pacific that has been omitted in studies of the wider Pacific. 
2. Flutes played with the nose are a particular type formerly played in numerous areas of the Pacific, and elsewhere globally. Except for Rapa Nui, nose flutes were previously played throughout the islands that comprise Polynesia (Moyle 1990a; Nunns 2014). In a comprehensive study, Ammann (2007) has shown that nose flutes were not likely indigenous to New Caledonia, Vanuatu and the Solomon Islands, but with some possible cases of the nose flutes in New Guinea. The historical record does not indicate flutes for the Marshall Islands or Kiribati (Fischer 1986), and thus I exclude these areas from this study. The history of different types of flutes in Micronesia, their status as indigenous instruments and the likely influence of cultural exchange has remained largely unexplored. My treatment of flutes does not assume an instrumental origin in the deep past, and questions remain about how representative flute types were over many islands in Micronesia.

3. Both types of flute were roughly $76 \mathrm{~cm}$ in length. The term bangsi also designates flutes in Southeast Asia; see Abels (2008: 283, note 329) for a comparison with the Palauan flute.

4. Finsch visited Kosrae between February and March 1880 but did not mention flutes in his published account, despite describing the instruments for elsewhere in the Caroline Islands (1893).

5. See Diettrich (2018) for a detailed examination of historical flute types on Pohnpei.

6. Haas (1906: 138) also described the use of a whistle on Yap made from a Calophyllum nut into which holes were bored.

7. Abels has speculated that the ngaok may not have been indigenous to Palau, citing that there are no indigenous stories about its origins (2008: 71). For sound recordings of Palauan flutes see the collections Chelitakl: Early Reel-toReel Recordings from Palau (2015) and Wax Cylinder Recordings from Palau, Micronesia, 1909/1936 (2011).

8. I use the term overtone flute to designate a flute without finger holes, and that is reliant on the harmonics produced.

9. For similar cultural contexts, see Buck (1957: 391) and Roberts (1926: 38) for Hawai'i, Ammann (2012: 64) for Vanuatu, Abels (2008: 67-68) for Palau, Haas (1906) for Yap, and Nunns (2014: 78-80) about the Māori kōauau (cross-blown flute).

10. As a musical style, engi are sung solo, are unmetered with vocables, exhibit recognised melodic and cadential patterns, and emphasise poetry about individuals or personal experiences.

11. An intriguing but unknown possibility is whether some flutes may have been given proper names, comparable to the naming of large breadfruit bowls and sailing vessels in Chuuk, and as for some instruments elsewhere in the Pacific Islands.

12. See for example the recent volume edited by Thomas, Adams, Lythberg, Nuku and Salmond (2016).

13. The second of these flutes, C3450, is capped at one end with a brass top of a rifle cartridge shell, with a hole in the shell casing to direct the air column in place of the usual piece of coconut (Evans 1974). Rifles were used in late 19th-century warfare in Chuuk before being confiscated by German colonial authorities in the early 20 th century. 


\section{REFERENCES}

Abels, Birgit, 2008. Sounds of Articulating Identity: Tradition and Transition in the Music of Palau, Micronesia. Berlin: Logos Verlag.

Ammann, Raymond, 1996. A revival of the ancient Kanak flute. Kulele 2: 47-56.

2007. Reality or fairytale? Nose flutes in Melanesian interactions. In R. Moyle (ed.), Oceanic Music Encounters: The Print Resource and the Human Resource. Auckland: Research in Anthropology and Linguistics, University of Auckland, pp. 1-12.

2012. Sounds of Secrets: Field Notes on Ritual Music and Musical Instruments on the Islands of Vanuatu. Münster: LIT Verlag.

Bates, Eliot, 2012. The social life of musical instruments. Ethnomusicology 56 (3): 363-95.

Bell, Joshua A. and Haidy Geismar, 2009. Materialising Oceania: New ethnographies of things in Melanesia and Polynesia. The Australian Journal of Anthropology 20: $3-27$.

Beynon, Ivor, G. Romani and Christopher Wagner, 2017 (accessed 22 July). Harmonica (i). Grove Music Online. Oxford Music Online. Oxford University Press. Available at: http://www.oxfordmusiconline.com/subscriber/article/grove/music/12384.

Bohlman, Philip V., 2016. Where they came from: Reracializing music in the empire of silence. In R. Randano and T. Olaniyan (eds), Audible Empire: Music, Global Politics, and Critique. Durham: Duke University Press, pp. 161-83.

Bollig, Laurentius, 1927. Die Bewohner der Truk-Inseln. Munster: Aschendorffsche Verlagsbuchhandlung. Unpublished translation by the Yale Cross-Cultural Survey in connection with the Navy Pacific Islands Handbook Series, 1967. New Haven: Human Relations Area Files.

Born, R., 1903. Einige Bemerkungen über Musik, Dichtkunst und Tanz der Yapleute. Zeitschrift für Ethnologie 35: 134-42.

Brown, Macmillan J., 1914. A new Pacific Ocean script. Man 14: 89-91.

Buck, Peter H., 1957. Arts and Crafts of Hawaii. Honolulu: Bernice P. Bishop Museum.

Cabeza Pereiro, Anacleto, 1895. La Isla de Ponapé. Manila: Tipo-Litografia de Chofre y Comp.

Cheyne, Andrew, 1971. The Trading Voyages of Andrew Cheyne 1841-1844. Edited by Dorothy Shineberg. Canberra: Australian National University Press.

Chelitakl: Early Reel-to-Reel Recordings from Palau. 2015. Museum Collection. Berlin. Ethnologisches Museum, Staatliche Museen zu Berlin. Recorded by Barbara B. Smith. Annotated by Birgit Abels. Produced by Lars-Christian Koch. Booklet and CD.

Christian, Frederick W., 1899. The Caroline Islands: Travel in the Sea of Little Lands. London: Methuen and Co.

Clement, Michael, 2001. The Ancient Origins of Chamorro Music. Unpublished Master's thesis, University of Guam.

de la Concha, Juan, 1887. Unpublished Report: List of Effects Recovered. 31 October. Pohnpei. Translation by Rodrigue Lévesque, 2005. In R. Lévesque (ed.), History of Micronesia: A Collection of Source Documents, Vol. 31. Québec: Lévesque Publications, pp. 661-64. 
Damm, Hans and Ernst Sarfert, 1935. Inseln um Truk. Ergebnisse der SüdseeExpedition 1908-1910. Part II. Ethnographie, B. Mikronesien, Vol. 6, part 2. Hamburg: Friederichsen, de Gruyter.

Dawe, Kevin, 2012. The cultural study of musical instruments. In M. Clayton, T. Herbert and R. Middleton (eds), The Cultural Study of Music: A Critical Introduction. New York: Routledge, pp. 195-205.

Diettrich, Brian, 2011. "Keeper-of-the-drum": Silent objects and musical pasts of Pohnpei, Micronesia. The Galpin Society Journal 64: 219-42.

2018 [in press]. Tracking flutes on nineteenth-century Pohnpei: Queries about instruments and their movements in the colonial Pacific. The Galpin Society Journal 71.

Diettrich, Brian, Jane Freeman Moulin and Michael Webb, 2011. Music in Pacific Island Cultures: Experiencing Music, Expressing Culture. New York: Oxford University Press.

Diettrich, Brian and Barbara B. Smith (comps), 2005. Catalogue of Field Recordings Made in Yap, Ulithi, Pohnpei, and Chuuk in 1963 by Barbara B. Smith. On file at the College of Micronesia-FSM and the University of Hawai'i at Mānoa, Pacific Collection.

Eilers, Anneliese, 1934. Inseln um Ponape. Ergebnisse der Südsee-Expedition 19081910. Part II. Ethnographie, B. Mikronesien, Vol. 8. Hamburg: Friederichsen, de Gruyter. 1936. Westkarolinen. Ergebnisse der Südsee-Expedition 1908-1910. Part II. Ethnographie, B. Mikronesien, Vol. 9, part 2. Hamburg: Friederichsen, de Gruyter.

El Comercio of Manila, 1890. News from the Carolines. 25 May 1890. Translation by Rodrigue Lévesque, 2005. In R. Lévesque (ed.), History of Micronesia: A Collection of Source Documents, Vol. 32. Québec: Lévesque Publications, pp. 487-93.

Evans, Donald, 1974. A Study of Musical Instruments from the Eastern Caroline Islands in the Bernice P. Bishop Museum Collection. Unpublished manuscript. Honolulu: East-West Center, Culture Learning Institute.

Finsch, Otto, 1893. Ethnologische Erfahrungen und Belegstücke aus der Südsee. Wien: Alfred Hölder.

Fischer, Hans, 1986. Sound-Producing Instruments in Oceania. Boroko, PNG: Institute of Papua New Guinea Studies.

Fischer, John L. and Ann M. Fischer, 1957. The Eastern Carolines. New Haven: Human Relations Area Files.

Flintoff, Brian, 2004. Taonga Pūoro: Singing Treasures. Nelson: Craig Potton.

de Freycinet, Louis Claude de Saulces, 1824. Voyage Autour du Monde. Paris: Chez Pillet Aîné

Girschner, Max, 1912. Die Karolineninsel Namoluk und ihre Bewohner. BasslerArchiv 2: 125-215.

Gladwin, Thomas and Seymour Sarason, 1953. Truk: Man in Paradise. New York: Wenner-Gren Foundation for Anthropological Research.

Goodenough, Ward H., 2002. Under Heaven's Brow: Pre-Christian Religious Tradition in Chuuk. Philadelphia: American Philosophical Society.

Gorenflo, Larry J., 1993. Demographic change in Kosrae State, Federated States of Micronesia. Pacific Studies 16 (2): 67-118. 
Haas, Salesius, 1906. Die Karolinen-Insel Yap. Berlin: Wilhelm Süsserot. Translated from the German in 1942 for the Yale Cross-Cultural Survey in connection with the Navy Pacific Islands Handbook Project. http://ehrafworldcultures.yale.edu/ document?id=or22-002.

Hahn, Hans Peter and Hadas Weiss, 2013. Introduction: Biographies, travels, and itineraries of things. In H. Hahn and H. Weiss (eds), Mobility, Meaning and Transformations of Things: Shifting Contexts of Material Culture Through Time and Space. Oxford: Oxbow Books, pp. 1-14.

Hambruch, Paul, 1936. Ponape. Ergebnisse der Südsee Expedition, 1908-1910. Part II. Ethnographie, B. Mikronesien, Vol. 7, part 2. Hamburg: Friederichsen, de Gruyter.

Hanlon, David, 2009, The "Sea of Little Lands": Examining Micronesia's Place in "Our Sea of Islands". The Contemporary Pacific 21 (1):91-110.

Harrington, Helmi Strahl and Gerhard Kubik, 2017 (accessed 22 July). Accordion. Grove Music Online. Oxford Music Online. Oxford University Press. Available at: http:// www.oxfordmusiconline.com/subscriber/article/grove/music/46180.

Harvey, Penny and Hannah Knox, 2014. Objects and materials: An introduction. In P. Harvey, E. Conlin Casella, G. Evans, H. Knox, C. McLean, E.B. Silva, N. Thoburn, K. Woodward (eds), Objects and Materials: A Routledge Companion. London: Routledge, pp. 1-18.

Hau'ofa, Epeli, 2005. Liner notes to: The Nose Flute Breathes Again, with Calvin Rore (CD). Suva: Oceania Centre for Arts and Culture, University of the South Pacific.

Herzog, George, 1932. Die Musik auf Truk. In Ergebnisse der Südsee Expedition 1908-1910. Part II. Ethnographie, B. Mikronesien, Vol. 5, part 2. Truk, pp. 384-404. Hamburg: Friederichsen, de Gruyter.

-1936. Die Musik der Karolinen-Inseln. In Ergebnisse der Südsee-Expedition 1908-1910. Part II. Ethnographie, B. Mikronesien, vol. 9, part 2. Westkarolinen, pp. 263-351. Hamburg: Friederichsen, de Gruyter.

Hezel, Francis X., 1995. Strangers in Their Own Land: A Century of Colonial Rule in the Caroline and Marshall Islands. Honolulu: University of Hawai'i Press.

Hodder, Ian, 2011. Human-thing entanglement: Towards an integrated archaeological perspective. Journal of the Royal Anthropological Institute 17: 154-77.

Ingold, Timothy, 2012. Toward an ecology of materials. Annual Review of Anthropology 41: 427-42.

Joyce, Rosemary A. and Susan D. Gillespie, 2015. Making things out of objects that move. In R. Joyce and S. Gillespie (eds), Things in Motion: Object Itineraries in Anthropological Practice. Sante Fe, New Mexico: School for Advanced Research Press, pp. 3-20.

Kaeppler, Adrienne, 1974. A study of Tongan panpipes with a speculative interpretation. Ethnos 39: 102-28.

-2001. Accordions in Tahiti-an enigma. In H.R. Lawrence (ed.), Traditionalism and Modernity in the Music and Dance of Oceania: Essays in Honour of Barbara B. Smith. Sydney: University of Sydney Press, pp. 45-66.

Krämer, Augustin, 1926. Palau. Ergebnisse der Südsee-Expedition 1908-1910. Part II. Ethnographie, B. Mikronesien, Vol. 3, part 3. Hamburg: Friederichsen, de Gruyter.

_ 1932. Truk. Ergebnisse der Südsee-Expedition 1908-1910. Part II. Ethnographie, 
B. Mikronesien, Vol. 5. Hamburg: Friederichsen, de Gruyter.

-1935. Inseln um Truk. Ergebnisse der Südsee-Expedition 1908-1910. Part II. Ethnographie, B. Mikronesien, Vol. 6, part 1. Hamburg: Friederichsen, de Gruyter.

-1937. Zentralkarolinen. Ergebnisse der Südsee-Expedition 1908-1910. Part II. Ethnographie, B. Mikronesien, Vol. 10. Hamburg: Friederichsen, de Gruyter.

Kubary, Jan S., 1889. Ein Beitrag zur Kenntniss der Ruk-Inseln. Mitteilungen der Geographischen Gesellschaft in Hamburg 7 (1887-1888): 53-63.

LeBar, Frank, 1964. The Material Culture of Truk. New Haven: Department of Anthropology, Yale University.

Lee, Kee-dong, 1976. Kusaiean-English Dictionary. Honolulu: The University of Hawai'i Press.

Logan, Mary, 1885. Letter to the Friends of the Micronesian Mission. 8 April. Boston: American Board of Commissioners of Foreign Missions.

McLean, Mervyn, 1968. An investigation of the open tube Maori flute or kooauau. Journal of the Polynesian Society 77 (3): 213-41.

1974. The New Zealand nose flute: Fact or fallacy? The Galpin Society Journal 27: 79-94.

1999. Weavers of Song: Polynesian Music and Dance. Auckland: Auckland University Press.

Merlin, Mark and James Juvik, 1996. Ira me Neeniier non Chuuk. Honolulu: EastWest Center.

Moral, Beatriz, 2002. Erotic legends and narratives in Chuuk, Micronesia. Micronesian Journal of the Humanities and Social Sciences 1 (1-2): 26-38.

Moulin, Jane Freeman, 1997. Gods and mortals: Understanding traditional function and usage in Marquesan musical instruments. Journal of the Polynesian Society 106 (3): 250-82.

Moyle, Richard, 1988. The Niuean nose flute. Anthropos 83 (4): 541-46.

1990a. The Polynesian nose flute. World of Music 32 (1): 29-48.

-1990b. Polynesian Sound-Producing Instruments. Princes Risborough, Buckinghamshire: Shire Publications.

Müller, Wilhem, 1917. Yap. Ergebnisse der Südsee-Expedition 1908-1910. Part II. Ethnographie, B. Mikronesien, Vol. 2, part 1. Hamburg: Friederichsen, de Gruyter.

Nunns, Richard, 2014. Te Ara Puoro: A Journey Into the World of Maori Music. Nelson, New Zealand: Craig Potton.

Nunns, Richard and Allan Thomas, 2005. The search for the sound of the pūtōrino: Me te wai e utuutu ana. Yearbook for Traditional Music 37: 70-79.

O'Connell, James F., 1972 [1836]. A Residence of Eleven Years in New Holland and the Caroline Islands. Edited by S.H. Riesenberg. Canberra: Australian National University Press.

Petersen, Glenn, 2009. Traditional Micronesian Societies. Honolulu: University of Hawai'i Press.

Plüddemann, Max, 1886. Bericht über die Reise S.M. Kr. "Albatross” von Matupi durch die Caroline und Palau-Inseln. Annalen der Hydrographie 14. Translation by Rodrigue Lévesque, 2005. In R. Lévesque (ed.), History of Micronesia: A Collection of Source Documents, Vol. 31. Québec: Lévesque Publications, pp. 209-212. 
Rainbird, Paul, 2003. Taking the tapu: Defining Micronesia by absence. Journal of Pacific History 38 (2): 237-50.

Ransom, Nathaniel C., 1871. Log of the Whaling Bark John Wells, Aaron Dean Master, 1869-1871. Log 769. New Bedford: Old Dartmouth Historical Society and Whaling Museum.

Riesenberg, Saul H., 1972. Introduction. In S.H. Riesenberg (ed.), A Residence of Eleven Years in New Holland and the Caroline Islands, by James O'Connell. Canberra: Australian National University Press, pp. 1-44.

Riesenberg, Saul H. and Shigeru Kaneshiro, 1960. A Caroline Islands Script. Washington: Smithsonian Institution, Bureau of American Ethnology.

Roberts, Helen H., 1926. Ancient Hawaiian Music. Honolulu: Bernice Pauahi Bishop Museum.

Sarfert, Ernst, 1919. Kusaie. Ergebnisse der Südsee-Expedition 1908-1910. Part II. Ethnographie, B. Mikronesien, Vol. 4, part 2. Hamburg: Friederichsen, de Gruyter. Scherzer, Karl, Ritter von. 1862. Narration of the Circumnavigation of the Globe by the Austrian Frigate Novara in the Years 1857, 1858, and 1859. London: Saunders, Otley.

Schmeltz, Johann D.E. and R. Krause, 1881. Ein Beitrag zur Kunde der Südsee-Völker. Die Ethnographisch-Anthropologische Abtheilung des Museum Godeffroy in Hamburg. Hamburg: L. Friederichsen \& Co.

Semper, Karl, 1873. Die Palau-Inseln im Stillen Ocean. Leipzig: F.A. Brockhaus.

Tanabe, Hisao, 1935. Masharu oyobi Karorin Gunto ni Okeru Ongaku to Buyo. Japanese Journal of Ethnology 1 (2): 258-76. Unpublished translation by Janet Roach, n.d. Weno, Chuuk, FSM, Micronesian Seminar.

-1968. Nan'yo, Taiwan, Okinawa Ongaku Kikô. Tokyo: Ongaku no Tomosha. Unpublished translation of Chapter Five (The Truk Islands) by Yoko Kurokawa, 2006. Personal collection of Brian Diettrich.

1978. The Music of Micronesia, the Kao-Shan Tribes of Taiwan, and Sakhalin. Recorded by Hisao Tanabe in Micronesia in 1934; sleeve notes and editing by Hideo Tanabe. Toshiba TW-80011. LP.

Thomas, Nicolas, 1991. Entangled Objects: Exchange, Material Culture, and Colonialism in the Pacific. Cambridge, Massachusetts: Harvard University Press.

Thomas, Nicholas, Julie Adams, Billie Lythberg, Maia Nuku and Amiria Salmond (eds), 2016. Artefacts of Encounter: Cook's Voyages, Colonial Collecting and Museum Histories. Dunedin: Otago University Press.

Troutman, John W., 2016. Kìkā Kila: How the Hawaiian Steel Guitar Changed the Sound of Modern Music. Chapel Hill: University of North Carolina Press.

Wax Cylinder Recordings from Palau, Micronesia, 1909/1936, 2011. Berliner Phonogramm-Archiv. Original recordings by Wilhelm Siemer and Paul Hambruch; transferred and edited by Albrecht Wiedmann. Annotated by Birgit Abels. Booklet and CD.

Wright, Michael, 2011. The Jew's harp trade in colonial America. The Galpin Society Journal 64: 209-18, 200.

2017 (accessed 22 July). Jew's harp. Grove Music Online. Oxford Music Online. Oxford University Press. Available at: http://www.oxfordmusiconline. com/subscriber/article/grove/music/14300. 
Yamaguchi, Osamu, 1967. The Music of Palau: An Ethnomusicological Study of the Classical Tradition. Unpublished Master's thesis, University of Hawai'i at Mānoa, Honolulu.

Zemp, Hugo, 1978. 'Are"Are classification of musical types and instruments. Ethnomusicology 22 (1): 37-67. 1981. Melanesian solo polyphonic panpipe music. Ethnomusicology 25 (3): 383-418.

Ziegler, Susanne, 2006. Die Wachszylinder des Berliner Phonogramm-Archivs. Berlin: Ethnologisches Museum, Staatliche Museen zu Berlin.

\section{ABSTRACT}

This article explores musical instruments in colonial Micronesia in their sonic, material and historical contexts. Using archival and oral sources and museum artefacts this study investigates the movements of instruments, including the abandonment of some and the acceptance of other types within Micronesian communities in the late 19th and early 20th centuries. The study argues for critical attention to the interplay of sound and silence within imperial enterprises in the Pacific, and it addresses the agency of musicians and listeners within a musical and material modernity. Specifically, this study also provides the first in-depth, comparative investigation of indigenous flutes from the Caroline Islands, as well as the first detailed cultural study of nose flutes from Chuuk in the Federated States of Micronesia. Through the investigation of historical flutes and colonial-derived instruments such as the harmonica I query how we understand the movements of things in their material and aesthetic forms, and I argue for the role of musical instruments in the unfolding of Pacific pasts and presents.

Keywords: Musical instruments, Chuukese nose flutes, colonial circuits, musical appropriation, indigenous modernity, cultural agency

\section{CITATION AND AUTHOR CONTACT DETAILS}

Diettrich, ${ }^{1}$ Brian, 2017. Instruments in motion: Flutes, harmonicas and the interplay of sound and silence in colonial Micronesia. Journal of the Polynesian Society 126 (3): 283-312. DOI: http://dx.doi.org/10.15286/jps.126.3.283-312

${ }^{1}$ Correspondence: Ethnomusicology, Te Kōkī New Zealand School of Music, Victoria University of Wellington, P.O. Box 600, Wellington 6140, New Zealand. Email: brian.diettrich@vuw.ac.nz 
